\title{
SURVIVAL OF SCOTCH THISTLE SEED BURIED AT THREE DEPTHS IN FOUR NEW ZEALAND SOILS
}

\author{
T.K. JAMES and A. RAHMAN \\ AgResearch, Ruakura Research Centre, Private Bag 3123, Hamilton \\ Corresponding author: trevor.james@agresearch.co.nz.
}

\begin{abstract}
Scotch thistle (Cirsium vulgare) is a stout biennial thistle growing to $1.5 \mathrm{~m}$ tall. Introduced more than a century ago and now abundant throughout New Zealand, it is mostly a problem in pastures. The viability of seed buried for 1-16 years at three depths was evaluated in four different soils. Seed samples buried in nylon mesh bags were removed after 1, 2, $3,5,11$ and 16 years burial and their viability determined by germination in the glasshouse. In the $0-20 \mathrm{~mm}$ layer it took from $1-4$ years, depending on soil type, for the viable seed numbers to fall to $1 \%$ of the original amount. At the 40-60 and 190-210 mm depths the amount of viable seed recovered after 16 years burial was considerably greater than at 0-20 $\mathrm{mm}$. Predicted intervals for the remaining viable seed to fall below $1 \%$ ranged up to 50 years, depending on soil type.
\end{abstract}

Keywords: Scotch thistle, Cirsium vulgare, buried seed, seed longevity, weed seed.

\section{INTRODUCTION}

Scotch thistle (Cirsium vulgare) is a stout, taprooted, biennial thistle originating from Eurasia (Webb et al. 1988). A prolific seed producer, it has been reported to produce up to 8000 seeds per plant (Klinkhamer \& De Jong 1993; Forcella \& Randall 1994). The seed is attached to a pappus for wind dispersal, but Klinkhamer et al. (1988) reported that $65 \%$ of seeds fell within $2 \mathrm{~m}$ of the plant and only $11 \%$ of the seeds were dispersed outside the local population. First recorded in 1867, Scotch thistle is now abundant throughout New Zealand. It is found in both crops and wasteland, but is mostly a problem in pastures where it has been shown to negatively impact the weight gain of sheep (Hartley 1983).

Scotch thistle, growing from seed, is a strong coloniser under both grazed and ungrazed pasture (Phung \& Popay 1981; Wardle et al. 1992), and is therefore difficult to control by grazing management. Although Scotch thistle seed has been reported to be predated to less than $1 \%$ within 6 months in its native environment (Klinkhamer et al. 1988), predation is likely to be considerably lower in New Zealand due to the absence of natural enemies and pathogens. As reproduction is entirely by seed, persistence of seed in the soil seedbank is very important. Therefore, knowledge of the viability of Scotch thistle seed in a variety of different soils is necessary for determining the likelihood of reinfestation of this weed (Forcella 1992).

This paper reports an experiment to evaluate the effect of burial depth, burial time and soil type on the viability of Scotch thistle seed. The experiment was replicated at four field sites with similar climate but widely varying soil characteristics.

\section{MATERIALS AND METHODS}

Four soil types commonly found in the Waikato region of New Zealand were selected for this study (Table 1). The Horotiu and Dunmore soils are both well drained, the Hamilton clay loam is moderately well drained and the Rukuhia peat is very poorly 
drained. The experiment was laid down in June 1981. Soil was collected from each site and heat-sterilised. For each site, 90 sets of $200(0.49 \mathrm{~g})$ freshly gathered Scotch thistle seed were mixed with the soil $(60 \mathrm{~g})$ and 60 sets were placed in fine nylon mesh bags $(0.25 \mathrm{~mm}$ mesh). For each site, 30 tubes $(250 \mathrm{~mm}$ length of perforated, $60 \mathrm{~mm}$ diameter plastic drainpipe) were filled with non-sterilised soil from the site. During this process, a seed/soil bag was placed in each tube at 40-60 mm and another at $190-210 \mathrm{~mm}$ from the top end of the pipe. The top $20 \mathrm{~mm}$ of the pipe was left free of soil and an unbagged seed/soil mixture was placed there, separated from the soil below by a layer of fine nylon mesh but uncovered at the top. The pipe sections were then buried vertically at the appropriate site with their tops flush with the soil surface. The tubes were arranged in a regular $10 \times 3$ matrix, $200 \mathrm{~mm}$ apart. The burial sites were in permanent pastures that were regularly grazed or mown.

TABLE 1: Descriptions and some characteristics of the soils used for this study.

\begin{tabular}{lccrrrc}
\hline Soil & \% sand & \% clay & \% $\mathrm{OC}^{1}$ & $\mathrm{pH}$ & $\begin{array}{c}\mathrm{CEC}^{1} \\
(\mathrm{meq} / 100 \mathrm{~g})\end{array}$ & $\begin{array}{c}\text { Field capacity } \\
(\% \mathrm{v} / \mathrm{v})\end{array}$ \\
\hline Horotiu sandy loam & 61 & 15 & 8.7 & 5.4 & 37.4 & 44.8 \\
Dunmore silt loam & 54 & 17 & 9.5 & 5.5 & 51.7 & 66.7 \\
Rukuhia peat & 24 & 16 & 49.1 & 4.6 & 103.6 & 60.7 \\
Hamilton clay loam & 29 & 31 & 4.6 & 5.6 & 28.2 & 36.8 \\
\hline
\end{tabular}

${ }^{1} \mathrm{OC}=$ Organic carbon; $\mathrm{CEC}=$ Cation exchange capacity.

At 2-4 monthly intervals for the first 3 years after burial, emerged seedlings were counted and removed from the top of the pipe sections. After 1, 2, 3, 5, 11 and 16 years, three randomly selected pipes were retrieved from each site in June or July and the viable seed from each depth assessed. Seed viability was determined by germination in an unheated glasshouse. The contents of each nylon bag and the 0-20 mm layer were spread thinly $(2-4 \mathrm{~mm})$ on paper towels laid over damp vermiculite in a tray. At approximately monthly intervals, emerged Scotch thistle seedlings were counted and removed. The soil was then thoroughly mixed and the procedure repeated until no further seedlings emerged (4-6 months).

\section{RESULTS AND DISCUSSION}

The viability of the original seed collected in autumn 1981, as determined by the Official Seed Testing Station, Palmerston North, was $80 \%$. This value was used to calculate the initial number of viable seeds (160) buried at each depth.

Results from the four sites show that seed viability was affected primarily by burial depth. The Scotch thistle seed mixed in the top $20 \mathrm{~mm}$ of the soil mostly disappeared within the first year (Fig. 1). Only a small percentage was lost through germination (Fig. 2). In the Rukuhia peat, Horotiu silt loam and the Dunmore silt loam soils, germination accounted for about $13 \%$ of the viable seed, while in the Hamilton clay loam soil it accounted for about $7 \%$ of the seed. No seed germinated in the field after the first year in any of the soils.

The disappearance of the seed placed at the 40-60 mm depth was much slower than that from the surface layer, with $1 \%$ to $15 \%$ of the original seed remaining viable in the soil after 16 years. At the 190-210 mm depth between $3 \%$ and $46 \%$ remained viable after 16 years. At the $40-60 \mathrm{~mm}$ depth seed disappeared fastest from the Dunmore silt loam soil while at the 190-210 mm depth seed disappeared fastest in the Hamilton clay loam soil. At both 40-60 mm and 190-210 mm depths seed persisted for the longest in the Horotiu sandy loam soil. (Fig. 1). 


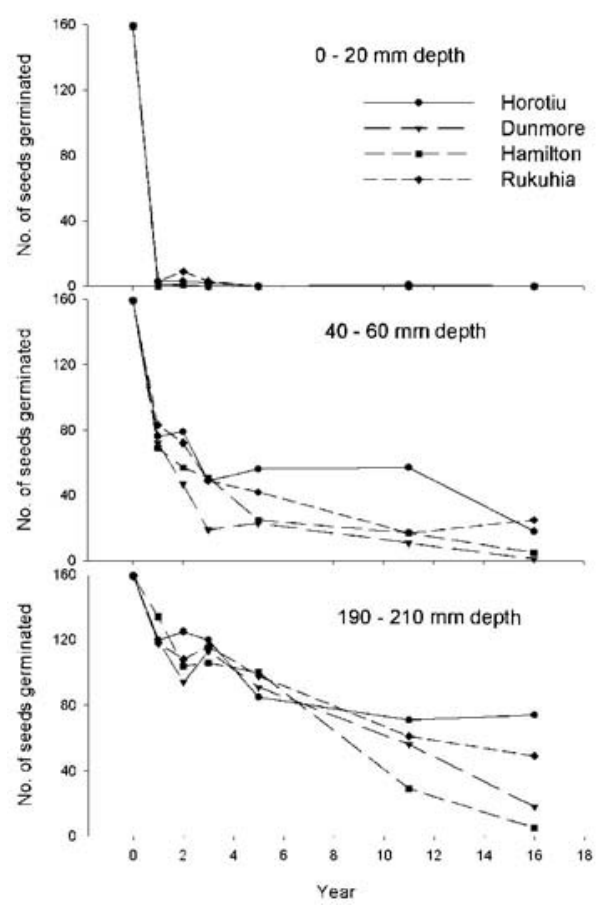

FIGURE 1: Number of Scotch thistle seeds which germinated after recovery from being buried at 0-20 mm, 40-60 $\mathrm{mm}$ and 190-210 $\mathrm{mm}$ depths in four different soils (average of three replicates).

The weed seed bank normally declines exponentially and this is readily explained in terms of biological processes, such as ageing, fungal parasitism and faunal predation (Thompson \& Makepeace 1983; Rahman et al. 1998). Therefore, an exponential model was used to examine these results and regression lines were fitted to logarithmic transformed data. From the regression equations the times for the amount of viable seed to be reduced to $1 \%$ of the original viable number were calculated and are presented in Table 2, together with the $\mathrm{R}^{2}$ of the fit. These data along with plotted results (Fig. 1) show that the decline of the buried Scotch thistle seed is consistent with exponential decay.

TABLE 2: Predicted time (years) for viable Scotch thistle seed numbers to be reduced to $1 \%$ of original viable seeds in four soil types at three depths.

\begin{tabular}{|c|c|c|c|c|c|c|c|c|}
\hline \multirow{2}{*}{$\begin{array}{l}\text { Soil depth } \\
(\mathrm{mm})\end{array}$} & \multicolumn{2}{|c|}{ Horotiu soil } & \multicolumn{2}{|c|}{ Dunmore soil } & \multicolumn{2}{|c|}{ Rukuhia soil } & \multicolumn{2}{|c|}{ Hamilton soil } \\
\hline & Years & $\overline{\mathrm{R}^{2}}$ & Years & $\mathrm{R}^{2}$ & Years & $\mathrm{R}^{2}$ & Years & $\mathrm{R}^{2}$ \\
\hline $0-20$ & 4 & - & 1 & - & 4 & - & 1 & - \\
\hline $40-60$ & 44 & 0.72 & 16 & 0.90 & 36 & 0.74 & 22 & 0.92 \\
\hline $190-210$ & $>50$ & 0.78 & 38 & 0.93 & $>50$ & 0.95 & 24 & 0.95 \\
\hline
\end{tabular}




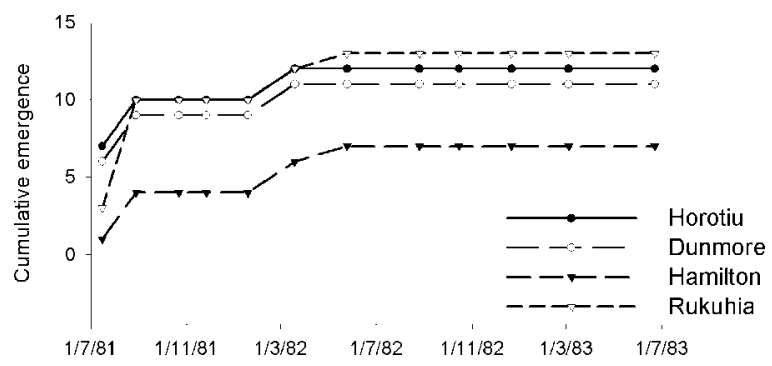

FIGURE 2: Cumulative emergence of Scotch thistle (total number of seedlings) in the field, from the 0-20 $\mathrm{mm}$ depth, during the first 2 years, in four different soils (average of three replicates).

The seed of Scotch thistle is clearly quite stable in a range of soil environments and remains viable for extended periods of time. This seed was most persistent in the Horotiu sandy loam where, over the 16 year period of this study, it only suffered moderate decay/ predation at the 190-210 mm depth. Thus, it would take some considerable time for the amount of viable seed to fall below $1 \%$ of the original amount in this soil. However, to extrapolate past the 50 year mark from these limited data is untenable, as the potential error becomes very large. Although this soil has the highest sand content, none of the measured soil characteristics truly set it apart from the others and thus it is difficult to understand why the deeply buried seed at this site remained viable in such large quantities. Of the other soils included in this study, the Dunmore silt loam soil is a hill country soil derived from volcanic ash but in many respects is similar to the Horotiu sandy loam soil. The Hamilton clay loam soil is also of volcanic origin but has a lower field capacity and is more prone to drying out. The Rukuhia peat is a recently developed peat soil with a very high organic carbon content and is frequently waterlogged. The absence of any large differences in seed longevity due to variations in soil properties indicates that Scotch thistle seed is able to resist the normal dynamics involved in the ageing and persistence of seed.

Our results from the soils in this experiment show that when placed on or near the soil surface, the seed of Scotch thistle did not remain viable for very long. But when buried at depths greater than $40 \mathrm{~mm}$, viable seed persisted for 16 to $>50$ years. These results are similar to those of Doucet \& Cavers (1996) who found that Scotch thistle seed did not persist beyond 6 months at or near the soil surface but when buried at $150 \mathrm{~mm}$ depth, between $45-75 \%$ of the seed remained viable after burial for 30 months depending on soil type. Also, these results show that Scotch thistle is considerably less persistent on the soil surface (1-4 years) than the related Californian thistle (8-16 years; James \& Rahman 2001). However, when buried, the seed of both thistle species persisted for similar periods. The implications of these results for management of this weed in pasture are positive. The rapid disappearance of the seed from the soil surface means that management practices that are likely to result in burying the seed should be avoided. These would include heavy stocking after rain, since pugging of soil is a well-known method of seed burial, and over-grazing during hot periods as seed can fall into badly cracked soil.

\section{ACKNOWLEDGEMENTS}

The authors wish to thank Alex Thompson and Bill Makepeace who carried out the seed burial and collected the data for the first five years. 


\section{REFERENCES}

Doucet, C.; Cavers, P.B. 1996: A persistent seed bank of the bull thistle Cirsium vulgare. Can. J. Bot. 74: 1386-1391.

Forcella, F.; Randall, J.M. 1994: Biology of bull thistle, Cirsium vulgare (Savi) Tenore. Rev. Weed Sci. 6: 29-50.

Forcella, F. 1992: Prediction of weed seedling densities from buried seed reserves. Weed Res. 32: 29-38.

Hartley, M.J. 1983: Effect of Scotch thistles on sheep growth rates. Proc. 36th N.Z. Plant Prot. Conf:: 86-88.

James, T.K.; Rahman, A. 2001: Longevity of buried Cirsium arvense seed in four New Zealand soils. Proc. Asian-Pacific Weed Sci. Soc. Conf. 18: 33-38

Klinkhamer, P.G.L.; De Jong, T.J. 1993: Biological flora of the British Isles: Cirsium vulgare (Savi) Ten. J. Ecol. 81: 177-191.

Klinkhamer, P.G.L.; De Jong, T.J.; Van Der Meijden, E. 1988: Production, dispersal and predation of seeds in the biennial Cirsium vulgare. J. Ecol. 76: 403-414.

Phung, H.T.; Popay, A.I. 1981: Effect of pasture cover on the germination of certain weed species. Proc. 34th N.Z. Weed and Pest Cont. Conf.: 111-113.

Rahman, A.; James T.K.; Bourdot, G.; Grbavac, N. 1998: Weed seedbank estimation, spatial distribution, decline and potential for predicting future weed populations. Plant Prot. Quart. 13(4):1-6.

Thompson, A.; Makepeace, W. 1983: Longevity of buried ragwort (Senecio jacobaea L.) seed. N.Z. J. Exp. Agric. 11: 89-90.

Wardle, D.A.; Nicholson, K.S.; Rahman, A. 1992: Influence of pasture grass and legume swards on seedling emergence and growth of Carduus nutans L. and Cirsium vulgare L. Weed Res. 32: 119-128.

Webb, C.J.; Sykes, W.R.; Garnock-Jones, P.J. 1988: Flora of New Zealand, Volume IV. Botany Division, D.S.I.R., Christchurch, New Zealand. 1365 p. 